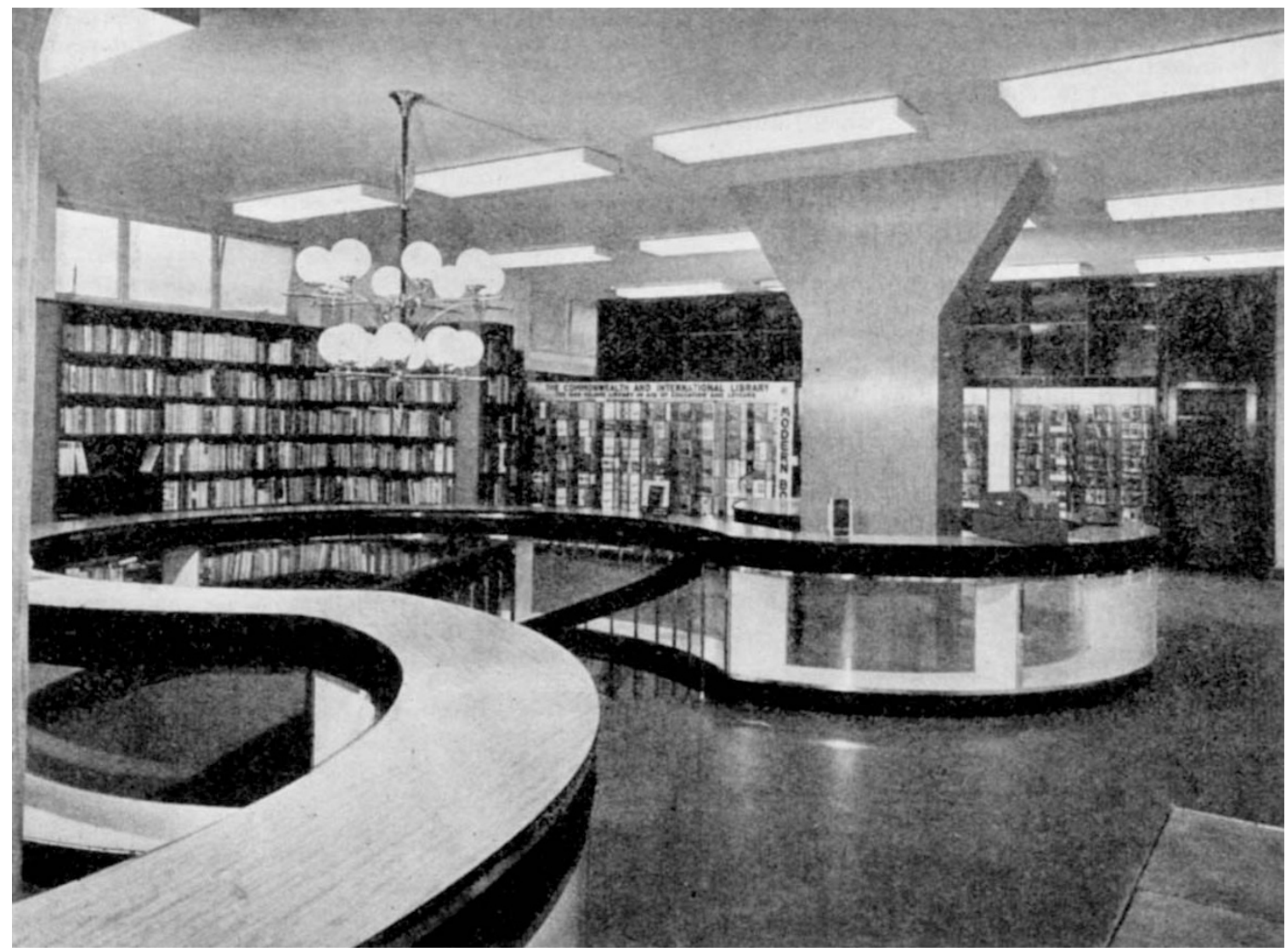

Fig. 1. Showcase and paperback book and journal section of the Maxwell bookshop in Magdalen College, Oxford

A further facility of interest to scientists is the stocking of a substantial range of scientific and medical books in German, French and Russian. There is also a "teachers and librarians only' room; in this room are displayed the latest text-books and terching aids.

Response from visitors from overseas suggests that Maxwell's will become the prototype of a chain of 'twentieth-century bookshops for university towns' all over the world. Following his recent tour of Maxwell's, for example, Dr. J. A. Matheson, vice-chancellor of the rapidly expanding Monash University, Victoria, Australia, invited Maxwell's to establish a bookshop on the University grounds at Clayton. A professor interested in plans for new buildings at Grenoble University has invited Maxwell's to participate. Long before these developments come to fruition, however, a second Maxwell's will be in operation in September opposite the University Medical Sehool in Edinburgh.

\title{
OBITUARIES
}

\section{Prof. Sidney Russ, C.B.E.}

Sidney Russ was born in London on December 2, 1879, and died on July 27, 1963. He started his career as a physicist in London, graduating from University College in 1905, after which he went to Manchester as demonstrator in physics. Here he spent five years in the exciting atmosphere of Rutherford's laboratories when new discoveries in radioactivity were almost a weekly occurrence. From this came his life-long interest in radioactivity, which led in 1910 to a most unusual step for a physicist to take. Having been awarded a Beit Memorial Fellowship, he docided to take it up in the new Cancer Research Laboratories of the Middlesex Hospital. This was followed in 1913 by his appointment as physicist to the Hospital, almost certainly the first appointment of its kind in the world and perhaps the starting point of a new branch of applied physics. In 1919 Russ transferred from Hospital to Medical School, and in 1920 was appointed to the newly instituted Joel chair of physics, which he held until his retirement in 1946.
During his early years at the Middlesex Hospital, Russ pioneered vigorously the application of precise physical principles and techniques to the use of radium and $X$-rays in medicine, a task for which his Manchester years well fitted him. Later his interests turned more to the biological and biophysical aspects of ionizing radiations, his greatest contribution probably lying in the field of radiation protection. His work with Gladys Scott on the biological effects of $\mathrm{X}$ - and gamma-rays at low doselevels, which seemed rather naive and crude at the time, was clearly pointing the way to the enormous range of investigations in this fiold carried out in recent years.

In 1919 there was growing concern about the hazards of the uncontrollod use of ionizing radiations. Russ became the first secretary of the British X-ray and Radium Protection Committeo, the first recommendations of which were published in 1920 . This slim document, produced before there was even an accepted unit of radiation dose, was quickly rocognized throughout the world and became the pattern for future codes of practice. In its style it clearly shows the imprint of the hand of Russ. 
Russ was scientific secretary of the National Radium Commission, secretary of the Medical Research Council Radiology Committee, president of the Röentgen Society, active in the affairs of the King Edward's Hospital Fund and the British Empire Cancer Campaign, and was awarded a C.B.E. in 1931 .

Large numbers of doctors will remember Sidney Russ as a teacher of both undergraduate medical students and radiologists. In many parts of the world, I have met ex-students who remember his concise, slightly pedantic lectures and his firm, but always kindly, demeanour in the examination room or laboratory. In the laboratory he was a hard taskmaster, given to flights of fancy but always firmly down to earth when results were produced. Many a humble research worker, both medical and nonmedical, struggling in the borderline field between physics and biology, has good reason to remember his kindly help and understanding.

The passing of Sidney Russ breaks one of the few remaining links with those exciting days when the new science of atomic physics invaded and revolutionized a major branch of the art of medicine.

\section{J. E. ROBERTS}

\section{Prof. G. M. Petropoulos}

Prof. George M. Petropoulos, director of the Laboratories of Electrical Measurements and High Voltage Engineering of the Technical University of Athens, died suddenly in Oslo on June 24 at the age of fifty-four. He had been attending a meeting of Committee No. 8 (Lightning and Surge Phenomena) of the Conférence Internationale des Grands Réseaux Électriques in Trondheim and was on his way back to Athens when he suffered a heart attack and died in his hotel.

After graduating in the Technical University of Athens in 1931, George Petropoulos joined the Piraeus Electricity Company and in 1937 went to the Technical University of Berlin for two years, where he began his researches on high-voltage phenomena for which he was so well known. He returned to the Piraeus Company for a few years and was appointed reader in 1946 and later professor in the Technical University, during which time he also acted as adviser to the Public Power Corporation. His main scientific contributions have been on transient electrical phenomena on transmission line systems, and on breakdown of air in uniform and diverging electrical fields, and it was on work on this latter subject that he was reporting in Trondheim. He had developed a vigorous research school in Athens and had become an authority on electrical discharges in gases.

His colleagues from many countries represented on the Conférence Internationale des Grands Réseaux Electriques will remember his quiet penetrating analysis of problems studied in committee, and his wise counsel will be greatly missed. He visited Britain many times, and was attracted to the English way of life; British scientists were always made very welcome when visiting him in Athens. He leaves a widow, one son and a daughter.

T. E. AlLIBone

\section{NEWS and VIEWS}

\section{Pure Mathematics at Leeds: Prof. A. W. Goldie}

Mr. A. W. Goldie, reader in algebra in King's College (University of Durham), Newcastle upon Tyne (renamed the University of Newcastle upon Tyne as from August 1) has been appointed to the newly established second chair of pure mathematics at the University of Leeds. Mr. Goldie took Part II of the Mathematical Tripos at Cambridge in 1941 , and then spent the rest of the war years in the Arma. ment Research Department, Ministry of Supply. After two years as an assistant lecturer in the University of Nottingham, he was appointed in 1948 to a lectureship at Newcastle, where he was promoted to senior lecturer in 1959 and to reader in 1960 . During the academic year 1960-61 he was a visiting research associate at Yale University. Apart from an excursion into functional analysis with two joint papers on Banach algebras, his research work has been entirely in algebra, with the theory of rings as his main field. A group of papers on non-commutative rings with maximum condition were of special importance and have aroused widespread interest. The break-through with which this work began was a complete structure theory for prime rings with maximum condition.

\section{U.S. National Bureau of Standards; New Appointments}

DR. R. D. Huntoon, at present deputy director, has been made responsible for managing the Standard Reference Data Program as deputy director for basic standards and services. Dr. Huntoon will continue to manage the Bureau's programmes associated with the development of basic measurement standards and for calibration services associated with the dissemination of the basic measurement standards. Dr. I. C. Schoonover, at present associate director, has been appointed to the newly created position of deputy director for technological standards and services. $\mathrm{He}$ will be responsible for all programmes involving the development of industrial standards and test methods, which provide a common basis for the exchange of technological products and services in industry and commerce. Associated with these changes, the Commodity Standards Division of the Office of Technical Services, U.S. Department of Commerce, has been transferred to the National Bureau of Standards to become part of the Bureau's increased and concentrated effort on technological standards. Dr. A. T. MePherson, formerly an associate director of the Bureau, and more recently associate director of the Office of Technical Services, is returning to the Bureau as special assistant to the director for international standards. R. B. Scott, at present acting director of the Bureau's Boulder Laboratories (Colorado), is appointed to the new position of manager of the Boulder Laboratories.

\section{Dr. R. D. Huntoon}

Dr. RoBert D. Huntoon has been a deputy director of the National Bureau of Standards for the past five years. For more than twenty years he has organized and directed fundamental research at the Bureau on atomic physies, electronic digital computers, electron physics, electronic instrumentation, and electronic ordnance devices, including guided missiles. Dr. Huntoon has been the recipient of many awards, including the Presidential Certificate of Merit and Department of Commerce Exceptional Service Award for his work on V.T. fuses, the Washington Academy of Sciences Award in Physical Sciences, etc. He joined the Bureau staff in 1941, and played an important part in the development of $\mathrm{V}$. T. fuses. From 1944 until 1946, Dr. Huntoon acted as consultant to the Secretary of War; in Europe, during this period, he assisted in the evaluation of $V$. T. fuses and electronic aids to bombing. In 1946, returning to the Bureau, he served in a succession of increasingly responsible posts, becoming chief of the Atomic and Radiation 